Wood Science and Technology Vol. 7 (1973) p. $251-265$

by Springer.Verlag 1973

\title{
Fibril Angle of Loblolly Pine Wood as Related to Specific Gravity, Growth Rate, and Distance from Pith
}

\author{
By Charles W. MoMillin \\ Southern Forest Experiment Station Forest Service, \\ U.8. Department of Agrioulture Alexandria, La.
}

\section{Summary}

Fibril angles were greater for earlywood (avg. 33.4 ${ }^{\circ}$ ) than for latewood tracheids (avg. $26.9^{\circ}$ ). For earlywood, fibril angle did not differ between growth rates when the specific gravity was low (avg. $33.3^{\circ}$ ). When the specifio gravity was high, wood of fast growth had a higher fibril angle (avg. $35.1^{\circ}$ ) than wood of slow growth (avg. $32.0^{\circ}$ ). No differences were detected between core, middle, and outer wood. In latewood tracheids, fibril angles were greater in corewood (avg. 28.0 $)$ than in middle or outer wood (avg. 26.3\%). For whole wood (a weighted average of earlywood and latewood), fibril angle averaged $30.7^{\circ}$ and was greater in corewood (avg. $32.2^{\circ}$ ) than in middle or outer wood (avg. $29.9^{\circ}$ ).

\section{Introduction}

In the research reported here, the fibril angle of a sample of Loblolly pine wood (Pinus taeda L.) was analyzed in relation to three readily measured gross wood characteristics. The characteristics or factors were specific gravity, growth rate, and distance from the pith. As in previous studies relating fiber morphology [McMillin 1968 a] and chemical constituents [McMillin $1968 \mathrm{~b}$ ] to these characteristics, wood was removed from many stems and stratified by two densities and two growth rates at each of three radial positions in the stem. Thus, the factorial design permitted isolation of the independent relationships of each factor with fibril angle. Characterizing wood types in this way is quite distinct from studying variation of fibril angles within stems.

Variation in fibril angle with height in the stem was not considered. Since only logs displaying $\mathbf{4 0}$ annual rings or more were selected, the study material came mostly from the lower 32 feet of the stems.

\section{Procedure}

Fifty Loblolly pines from a stand near Alexandria, La., were felled and bucked. After logs with visible defects had been discarded, the remainder was slabbed on two sides to the 10th annual ring. The resulting cant was ripped along the 10th, 20 th, and 30th rings to form five boards. Wood beyond the 30 th ring was discarded. Specific gravity (ovendry weight and green volume) was determined on a 1-inch sample cut from the midpoint of each board. On the basis of these preliminary measurements, 200 pounds of wood were selected for each category in each of two replications in the factorial design outlined below. Boards having specific gravities and growth rates near the category division points were rejected. 
The detailed procedures for tree selection and specimen preparation are described in the earlier paper [MoMillin 1988a].

Varisbles in the design were:

Unextracted specific gravity (ovendry weight and green volume)

Low (lees than 0.49)

High (more than 0.49)

Growth rate

Fast (lees than 6 rings per inch)

Slow (more than 6 rings per inch)

Position in tree (number of rings from pith)

Corewood $(0-10)$

Middle wood (11-20)

Outer wood $(21-30)$

The stratification of wood into these 12 factorial categories was possible becsuse, for a given number of rings from the pith, the range of variation in specific gravity and growth rate between stems is remarkably large. For example, it is possible to isolate corewood of low density and slow growth from one stem, while corewood from a second stem may be of low density and fast growth. As another example, the outer wood of one stem and the corewood of a second stem may both contain fast-grown wood of high density.

Sample boards in each replication and each category were separately reducod to chipe that averaged somewhat less than 1 inch in length, and a random subsample of 1,000 chips was taken from each of the 24 groupa.

Specific gravity of unextracted wood was measured on 500 of the sample chips; the method was that of Smith [1961]. Wood of low grevity averaged 0.45, while wood of high gravity averaged 0.53 . Since growth rate in rings per inch and proportion of latewood could not be determined from chip, these measurements were taken beforehand on the samples used for segregating the boards. Because boards had variable cross-sectional areas, measurements were weighted by area in calculating the mean growth rates. Average values were 6.1 and 9.2 rings per inch for slow. and fast-grown wood respectively.

Forty chips, randomly selected from each 1,000-chip sample, were diseected into earlywood and latewood slivers and macerated for 2 deys in a 50/50 solution of 30-percent hydrogen peroxide and glacial acetic acid at $50^{\circ} \mathrm{C}$. Fibril angles were measured on the macerated tracheids by a polarized light technique [Preston 1952, p. 116]. The method employs a polarizing miorosoope equipped with a first-order red retardation plate positioned at $46^{\circ}$ to the direction of light vibration and an eyepiece reference line placed parallel to the light vibration. At the major extinction poaition, the fibrillar structure of the cell wall is in the direction of vibration of the polarizer and is the same color as the beckground (a reddish purple). After the major extinction position has been located, the angular position of the stage is recorded. The stage is then rotated so that the lengthwise axis of the tracheid is parallel to the eyepiece cross-hair. A second angular reading is noted, and the difference between the two readings is taken as the fibril angle of the tracheid. 
One hundred fibril-angle determinations were made on separate tracheids from each of the forty-eight wood samples and the results averaged. In all cases, measurements near bordered pits were avoided.

Statistical differences were detected by analysis of variance at the 0.05 level.

\section{Results}

Table 1 summarizes the wood properties and fibril angles for each wood category. Gross wood properties exhibited a wide range and reflected the method of specimen preparation. Individual values for unextracted specific gravity ranged

Tabele Averaged result of wood properties and fibril angle determinations ${ }^{1}$

\begin{tabular}{|c|c|c|c|}
\hline \multirow{3}{*}{$\begin{array}{l}\text { Position (rings from pith) } \\
\text { and unextrected speoifio } \\
\text { gravity } \\
\text { g/cms }\end{array}$} & \multirow{2}{*}{ Growth reto } & \multicolumn{2}{|l|}{ Fibril angle } \\
\hline & & Earlywood & Latewood \\
\hline & rings/inch & degrees & \\
\hline \multicolumn{4}{|l|}{ Core $(0-10)$} \\
\hline 0.43 & 4.4 & 34.3 & 26.2 \\
\hline .45 & 8.7 & 33.9 & 27.0 \\
\hline .50 & 4.6 & $\mathbf{3 6 . 0}$ & 30.8 \\
\hline .51 & 11.8 & 32.8 & 28.1 \\
\hline \multicolumn{4}{|l|}{ Middle $(11-20)$} \\
\hline .43 & 5.5 & 32.7 & 24.9 \\
\hline .47 & 7.0 & 33.0 & 26.6 \\
\hline .63 & 4.8 & 34.4 & 24.9 \\
\hline .54 & 10.4 & 32.4 & 27.1 \\
\hline \multicolumn{4}{|l|}{ Outer $(21-30)$} \\
\hline .46 & 5.1 & 32.9 & 26.7 \\
\hline .44 & 8.2 & 32.9 & 27.2 \\
\hline .57 & 6.9 & 34.9 & 27.4 \\
\hline .52 & 9.1 & 30.8 & 27.0 \\
\hline
\end{tabular}

1 The values for fibril angle are beed on 200 obeervations; the values for unextracted chip specifio gravity and growth rate are based on two obeervations.

from 0.42 to 0.63 , while rings per inch of growth rate ranged from 4.1 to 12.4. Correlations ( $r$ values) between the independent variables of specifio gravity, growth rate, and number of rings from the pith were low (less than 0.23). The factorial design avoided certain relationships that exist in a tree stem. For example, the correlation coefficient between unextracted specific gravity and number of rings from the pith was 0.23 because wood of both high and low gravity was considered at all positions.

When comparing the data of Table 1 to that of other researchers, it should be noted that the various methods of measuring fibril angle do not yield identical results. Preparatory to the present experiment, it was observed that the polarized 
zht technique (applied to macerated latewood tracheids of spruce pine) indicated bril angles about $8^{\circ}$ larger than those indicated by pit apertures observed in idial sections. Regression analysis ahowed that values obtained by the two lethods were alosely correlated $\left(r^{2}=0.86\right)$. On mounted latewood tissue, the slarized light method indicated $4^{\circ}$ to $5^{\circ}$ larger fibril angles than the commonly sed wall-check method $\left(r^{2}=0.71\right)$.

As expected, fibril angles were consistently higher in earlywood (avg. $33.4^{\circ}$ ) Ian in latewood tracheids (avg. $26.9^{\circ}$ ) regardless of wood specific gravity, growth ste, and rings from the pith.

In earlywood tracheids, fibril angle did not differ between core, middle, or uter wood. However, the interaction of specific gravity and growth rate was ignificant.

Earlywood fibril angle was greatest in fast-grown wood of high specific ravity (avg. $35.1^{\circ}$ ). Fibril angle did not differ between growth rates when the pecific gravity was low; the average was $33.3^{\circ}$. When the specific gravity was igh (more than 0.49), wood of fast growth had a higher angle (avg. $36.1^{\circ}$ ) than rood of slow growth (avg. $32.0^{\circ}$ ).

In latewood, values differed with number of rings from the pith. No differences rere detected between growth rates and specific gravities. When averaged over II levels of apecific gravity and growth rate, latewood fibril angle decreased from $8.0^{\circ}$ for corewood to $25.6^{\circ}$ for middle wood. The value for outer wood increased lightly (avg. $27.1^{\circ}$ ) and did not differ significantly from that of middle wood. $n$ addition, fibril angle of outer wood did not differ from that of corewood. $f$ latewood fibril angles from wood with 0 to 10 and 11 to 30 rings from the pith se compared, the averaged values are 28.0 and $26.3^{\circ}$.

If the dimensions of cells in the tangential direction are assumed constant at unity, it can be hown that the fibril angle of normal wood (i.e., wood containing roth earlywood and latewood tracheids) is a function of the fibril angle and lumber of oells per unit volume of each tissue type and their respective volume rercentages. From this analysis, a weighting equation was developed:

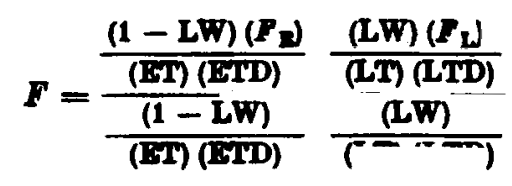

shere

$$
\begin{aligned}
F & =\text { weighted fibril angle of the carlywood-latewood composite } \\
F_{\mathbf{E}} & =\text { fibril angle of earlywood } \\
F_{\mathrm{L}} & =\text { fibril angle of latewood } \\
\mathbf{L W} & =\text { proportion of latewood } \\
\mathbf{E T} & =\text { earlywood tracheid length in millimeters } \\
\mathbf{E T D} & =\text { earlywood tracheid diameter in miorometers } \\
\mathbf{L T} & =\text { latewood tracheid length in micrometers } \\
\mathbf{L T D} & =\text { latewood tracheid diameter in micrometers }
\end{aligned}
$$


The fibril angles of table 1 were weighted by this procedure. The values for proportion of latewood and cellular dimensions were those obtained from the earlier research [McMillin 1968a] with samples of the same material employed in the present study. When these weighted values were averaged over all growth rates, specific gravities, and rings from the pith, fibril angle was $30.7^{\circ}$. By variance analysis, it differed with only one study factor: rings from the pith. It was significantly higher in corewood (avg. $32.2^{\circ}$ ) than in middle or outer wood (avg. $29.9^{\circ}$ ).

\section{Relerences}

MoMillin, C. W. 1968 a. Morphological oharacteristios of Loblolly pine wood as related to specific gravity, growth rate and distance from pith. Wood Sci. Toohnol. 8: 166-176.

McMillin, C. W. 1968 b. Chemionl composition of Loblolly pine wood as related to specific gravity, growth rate, and distance from pith. Wood Soi. Technol. 2 : 233-240.

Preston, R. D. 1952. The molecular architecture of plent cell walls. London: Chspman and Hall, Ltd.

Smith, D. M. 1961. Method of determining specific gravity of mood chips. U.S. Dept. Agriculture, Forest Serv., For. Prod. Lab. Rop. 2209. Madison, Wis.

(Roceived Ootober 10, 1971)

Charles W. MoMillin, Southern Experiment Station, Forest Bervice UBDA, Alexandria, La. USA 